International Journal of Current Microbiology and Applied Sciences

ISSN: 2319-7706 Volume 6 Number 3 (2017) pp. 276-282

Journal homepage: http://www.ijcmas.com

Original Research Article

https://doi.org/10.20546/ijcmas.2017.603.030

\title{
Production of Millet-Based (Pennisetum glaucum) Ablo and Sorghum-Based (Sorghum bicolor) Ablo Cultivated in the Republic of Benin
}

\author{
Jultesse S.B. Banon $^{1}$, Innocent Yaou Bokossa ${ }^{1}$, Célestin C.K. Tchekessi ${ }^{1}$, Roseline
} Bleoussi $^{1}$, Pivot Sachi ${ }^{1}$, Anayce Djogbe ${ }^{1}$, Karl Assogba ${ }^{1}$, Farid Bade ${ }^{1}$, Edwige DahouenonAhoussi $^{2}$, Azokpota Paulin ${ }^{3}$ and Guy Apollinaire Mensah ${ }^{4}$

${ }^{1}$ Research Unit in Safety Health Food (URSSA), Laboratory of Microbiology and Food Technology (LA.MI.TA), Department of Plant Biology, Faculty of Sciences and Techniques

(FAST), University of Abomey - Calavi (UAC), Cotonou 04BP 1107, Benin

${ }^{2}$ Food Technology Genius Laboratory, Polytechnic School of Abomey-Calavi (EPAC), University of Abomey-Calavi (UAC), Benin

${ }^{3}$ Laboratory of Molecular Biology and Formulation of Food, Department of Nutrition, Food Science and Technology, Faculty of Agronomic Sciences (FSA), University of Abomey-Calavi

(UAC), 01BP 526 Cotonou, Benin

${ }^{4}$ National Institute of Agricultural Research of Benin (INRAB), 01 BP 884 Main Recipe, Cotonou 01, Benin

*Corresponding author

\section{A B S T R A C T}

Keywords

Ablo, Millet,

Sorghum,

Fermentation,

Benin.

Article Info

Accepted:

10 February 2017

Available Online:

10 March 2017
Ablo is a wet bread, slightly salty and sweet, steamed and sold in the form of pellets. The study is intended to develop the production's technology of two new types of Ablo. The methodology adopted consists of carrying out production tests according to the original process described by Aholou-yeyi (2007) modified. The results showed that production of sorghum-based Ablo technology and production of millet-based Ablo technology followed four main steps, namely: the preparation of flour, the preparation of the dough to ferment, fermentation and cooking. Fermentation lasted 2-3 hours for the millet-based Ablo and 3 hours for the Ablo made from sorghum. The cooking time of the fermented dough was 15 to 20 minutes. Millet-based Ablo and sorghum-based Ablo had an alveolar structure and were more consistent than the fermented dough.

\section{Introduction}

The major part of the human food supply is provided by cereals such as the millet, sorghum, corn, rice, wheat, and barley. These cereals are subjected to several types of transformations which include fermentation very practiced in Africa. The fermentation is one of the oldest and more economic methods of production and preservation of food (Steinkraus et al., 1983; Cook et al., 1987; Chavan and Kadan, 1989). Sorghum (Sorghum bicolor) is a Poacee (ex-graminee) belonging to the sub family of the Panicoidees 
and to the tribe of the Andropogonees (Clerget, 2004). The sorghum domestication took place in the southeast of the African deserts margin, in an area now occupied by Sudan and Ethiopia, 5.000 to 8.000 years ago (Wendorf et al., 1992). In Africa, this production reached about 21 million tonnes (Akakpo, 2013). In Benin, the national grain sorghum production was estimated at 107.969 tonnes in 2013 (APRM, 2013). With this production, sorghum is the third largest in cereal production in the country after the maize and rice. It is most widely grown in the North than in other parts of the country. Yields are estimated on average at 1.010 $\mathrm{kg} / \mathrm{ha}$ with the lowest observed in the regions of South and Central (APRM, 2013).

Millet (Pennisetum glaucum) is native to tropical West Africa. There are approximately 2000 years, this culture was introduced in East, Central Africa and India where, due to its excellent tolerance to drought, it established itself in the drier environments (FAO, 1995). The term millet includes a set of annual food grasses that are distinguished by their colors, their forms and their sizes (Tou, 2007). In Benin, the millet has been estimated to 31.023 production about tonnes in 2013 (APRM, 2013). This production is done only in the northern part of the country, in the Alibori, Atacora departments and especially in the Donga.

Fermented foods are an important component in the human diet for thousands of years. But they are often produced in uncontrolled conditions giving rise to a wild fermentation. Several of these fermented products are still badly known and come from cereals, roots and tubers and legumes.

This study focused on Ablo which is a moist bread shaped ball, very consumed in Benin, especially in large cities (Abrams et al., 2013; Dan, 2013; Houssou et al., 2014; Aboudou et al., 2014; Houssou et al., 2015). It is intended to develop the technology of production of two types of Ablo sorghum and millet based.

\section{Materials and Methods}

The productions were made in the Research Unit in Safety Health Food (URSSA) of the Laboratory of Microbiology and Food Technology in the Faculty of Sciences and Techniques (FAST) located at the Applied Biomedical Sciences Institute (ISBA) of the University of Abomey-Calavi (UAC).

\section{Plant material}

Sorghum (Sorghum bicolor) of red color designated in local language fon by "abokun" and the small millet (Pennisetum glaucum) called greenish color "likun" in fon were used. Wheat flour also served as plant material. These cereals were purchased at the Dantokpa Cotonou's international market.

\section{Biological material}

The instant yeast (Saccharomyces cerevisiae) of trademark PASHA made in Turkey by DOSU MAYA MAYACILIK A.S. Company certified ISO 9001: 2008 has been used. It was purchased at the Dantokpa Cotonou's international market. It is used as a leaven in the manufacturing technology of the Ablo (Ahokpe, 2005; Aholou-Yang, 2007; Bokossa et al., 2013).

\section{Other material}

The material used for the different manufacturing consisted of ingredients (sugar, salt) and standard production equipment of the Ablo such as basins, plastic buckets, pots, a colander or own basket, a spatula, a whip, a mill wheels, a sieve, a tray with perforations, of mussels and a home. The water of the national society of Benin (SONEB) waters was also used. 


\section{Method of production}

The production tests were conducted according to the original method described by Aholou-yeyi (2007) changed. The difference in this technology was the use of other types of cereals such as millet and sorghum and the reduction of the fermentation time.

\section{Calculation of yield}

Production yields were calculated on the basis of the weight according to the following formula:

Yield $(\%)=[($ weight of the final product $) \mathrm{x}$ 100] / (weight of the initial product)

\section{Results and Discussion}

The production's technologies of Ablo using sorghum and millet followed four main steps, namely: the preparation of flour, the preparation of the dough to ferment, fermentation and cooking.

\section{The preparation of flour}

The preparation of flour involved several steps such as:

- Cleaning where the grain sorghum and millet were rid of various impurities (rotten grain, foreign grain, plant debris, insects, metal fragments, stones and other waste) by winnowing and sorting by hand.

- Washing and soaking consisted in separating totally the grains of any waste left after sifting. These wastes (rotten grain, plant and insect debris) dated back to the surface of the water and were eliminated with this one.
- Fine grinding to get the flour more or less wet.

\section{The preparation of the dough to ferment}

One-third (1/3) of previously obtained flour was used to prepare a mush. This porridge was cooked to a paste. Cooking was stopped immediately after getting the dough to avoid cooking also this last.

\section{The fermentation}

After cooling the previously dough, $2 / 3$ of the remaining flour were added. The mixture was undergoing a first kneading. This mixture to which were added the salt and instant yeast wheat flour was undergoing a second kneading. The whole was covered and allowed to rest at room temperature (25 to $30^{\circ} \mathrm{C}$ ) for $2-3$ hours for the dough of millet and 3 hours to that of sorghum.

\section{Cooking}

The previously fermented dough was slightly sweet and distributed in small metal containers lined plastic packaging, all arranged on a van. The van filed inside an aluminum basin in which the steam produced by boiling water, occupying the bottom of the pot, allow to cook paste fermented. The cooking time of the fermented dough was 15 to 20 minutes. The Ablo cooked had a honeycomb and was more consistent than the fermented dough. Cooking at the same time played the role of pasteurization.

Figure 1 and 2 present respectively technological diagrams of the Ablo production using millet or sorghum. The production output of the paste was $380 \%(\mathrm{p} / \mathrm{p})$ or $1 \mathrm{~kg}$ of grain was on average $3.8 \mathrm{~kg}$ of fermented dough. 
Figure.1 Technological diagram of millet-based Ablo production

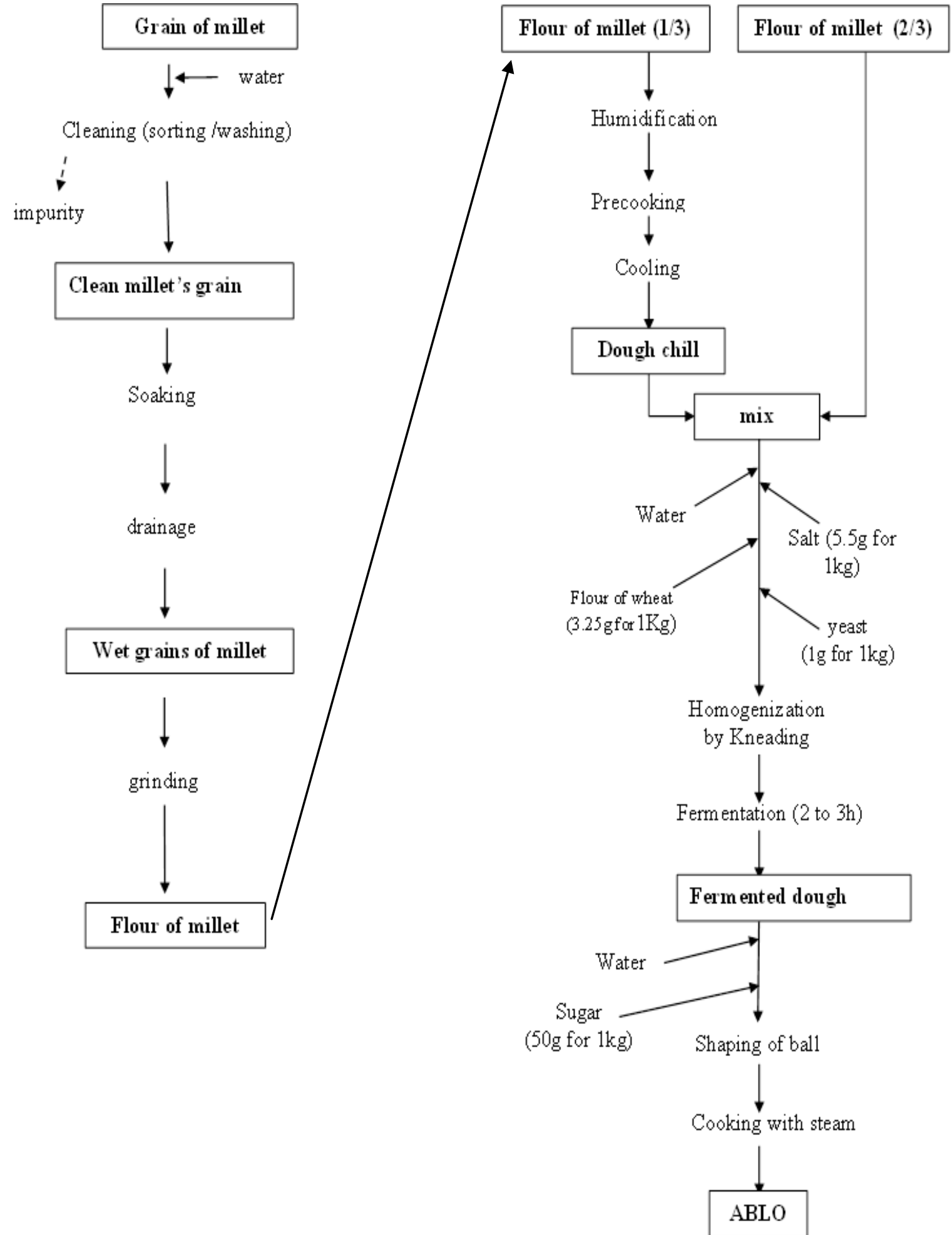


Figure.2 Technological diagram of sorghum-based Ablo production

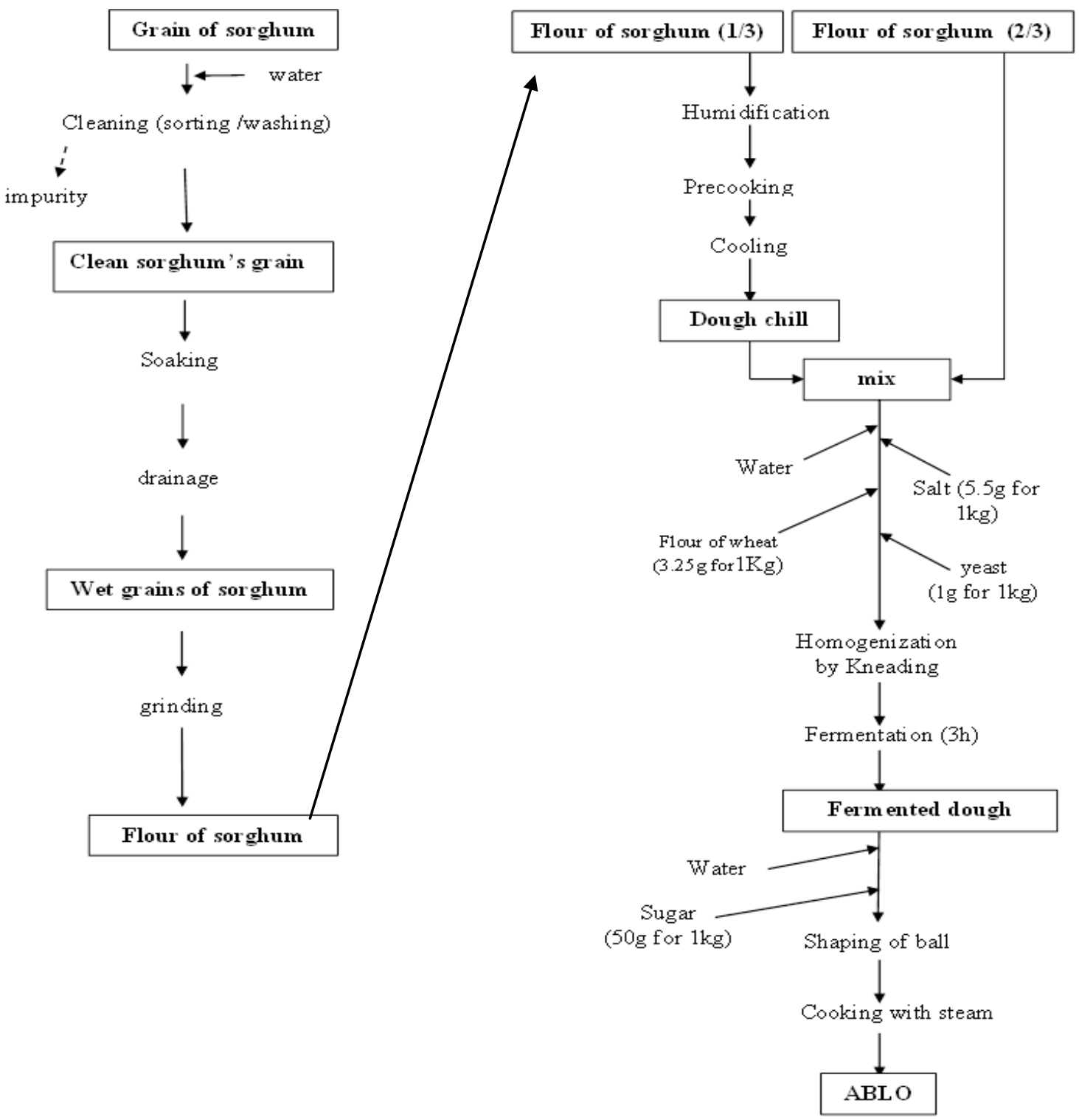

Works show that Ablo production's technologies using sorghum or millet follow four main steps. These results are consistent with those obtained by Ahokpe (2005), Banon (2012) and Bokossa et al., (2013) on the Ablo of the rice, who said that the preparation of flour, the dough to ferment preparation, fermentation and cooking are Ablo production steps.

The fermentation takes place at room temperature $\left(25\right.$ to $\left.30^{\circ} \mathrm{C}\right)$ for 2 to 3 hours for the dough of millet and 3 hours to that of sorghum. This fermentation being stimulated by yeast is not spontaneous. However the microflora present in the grain, on equipment used or contaminated during grinding would play a role in the fermentation. These results are consistent with those obtained by Ahokpe (2005) and Aholou-Yang (2007) on the Ablo corn who pointed out that the microflora present in grain corn, the equipment used and in the mawe or contaminated during grinding play a role in the fermentation. 
The two technologies developed have a lower production-term than existing technologies. They exclude long preparation of the mawe and painful step. Thus, these two technologies better meet the aspirations of women producers and Ablo vendors who brought them to a substitution or part of corn by rice. The vendors will win so much more time and energy compared to other technologies. Production of the Ablo millet-based and sorghum-based contributes to the diversification of the types of Ablo produced in Benin but also to the enhancement of our local agricultural products.

The cooking time of the fermented dough is 15 to 20 minutes. The cooked Ablo presents a honeycomb and is more consistent than the fermented dough. Cooking at the same time played the role of pasteurization and is responsible for the removal of the vegetative form of microorganisms and eventual flora of contamination. The same comments were made by Leclerc et al., (1977), Akapko (2013), Agro (2013) and by Bokossa et al., (2016) who showed that thermal treatment of seconds at $72^{\circ} \mathrm{C}$ is sufficient to destroy the vegetative forms of microorganisms in food products.

In conclusion, this study allows the technology development of production of two types of Ablo. It also contributes to the widening of ranges of grain products eaten in Benin. So, the millet-based Ablo and the sorghum-based Ablo are two kinds of Ablo manufactured using two new production technologies.

The vendors will win so much more time and energy compared to other technologies. These two types of Ablo are new products developed and deserve to be known to the general public through a good program of promotion of grain foods fermented from Benin.

\section{References}

Aboudou, A., Akissoé, N., Mestres, C. et Hounhouigan, D.J. 2014. Optimisation de la fermentation en milieu semi-solide pour la production d'ablo, pain cuit à la vapeur d'Afrique de l'ouest. J. Appl. Biosci., 82: 7469- 7480 ISSN 19975902.

Agro, D.A. 2013. Optimisation des conditions de fermentation de la pâte pour la préparation de l'ablo a base du riz. Mémoire de Master, soutenu à la FAST/UAC, 56 p.

Ahokpe, K.F. 2005. Valorisation des aliments traditionnels locaux: Evaluation des procédés traditionnels de préparation de Ablo, une pate fermentée cuite à la vapeur. Thes. Maît., FAST/UAC, 51P.

Aholou-yeyi, A.M. 2007. Evaluation du système technique artisanal de production de $A b l o$, un pain cuit à la vapeur. Thèse. Ing. Agr, FSA/UAC, 61p.

Ahoyo, A.N.R., Djinadou, A.K.A., Adégbola, Y.P., Allagbe, C.M., Gotoéchan, M.H., Adjanohoun, A. et Mensah, G.A. 2013. Technologies améliorées de production, de conservation et de transformation du maïs existantes au Bénin. Résumé du document Technique et d'Information. MAEP/ProCAD/PPAAO/CNS-Maïs et INRAB/Bénin. 117 p. Dépôt légal $\mathrm{N}^{\circ}$ $6947 \mathrm{du} 04$ novembre 2013, 4ème trimestre 2013, Bibliothèque Nationale (BN) du Bénin ISBN : 978 - 99919 - 1 612 - 5 En ligne.

Akakpo, A.D. 2013. Influence du taux d'incorporation des farines (maïs, riz, ble) sur les caracteristiques physico-chimiques et sensorielles de "ablo". Mémoire de Master, soutenu à la FAST/UAC, 56p.

Banon, S.B.J. 2012. Evolution de la flore microbienne au cours de la fermentation d'un produit alimentaire fermenté du Bénin: cas de Ablo. Mémoire de Master, soutenu à la FAST/UAC, 57 p.

Bokossa, I.Y., Banon, J.B.S., Tchekessi, C.K.C., Dossou-Yovo, P., Adeoti, K., et 
Assogba, E. 2013. Evaluation socioéconomique de la production de Ablo, une pâte de maïs fermentée du Bénin. Bulletin de la Recherche Agronomique du Bénin. Numéro spécial, 35-40.

Bokossa, Y.I., Banon, S.B.J., Tchekessi, C.K.C., Sachi, P., Djogbe, A. and Bleoussi, R. 2016. Production de Ablo, un aliment céréalier fermenté du Bénin: Synthèse bibliographique. Int. J. Innovation and Appl. Studies, Vol. 16 No. 2 Jun. 2016, pp. 356-369.

Chavan, J.K. et Kadam, S.S. 1989. Nutritional improvement of cereals by fermentation. Crit rev. Food Sci. Nutri., 28(5): 357-400.

Clerget, B. 2004. Rôle du photopériodisme dans l'élaboration $\mathrm{du}$ rendement de trois variétés de sorgho cultivées en Afrique de l'ouest. Thèse de Doctorat, Institut National Agronomique Paris-Grignon, $192 \mathrm{p}$.

Cooke, R.D., Twiddy, D.R. and Reilly, P.J. A. 1987. Lactic acid fermentation as a lowcoast means of food preservation in tropical countries. FEMS microbiol. Rev., $46: 369-379$.

Dansou, V. 2013. Utilisation de variétés locales de riz pour la production de Ablo au Bénin. Mémoire pour l'obtention du diplôme d'Ingénieur de conception. Option: Génie de Technologie Alimentaire. Ecole Polytechnique d'Abomey-Calavi, Université d'AbomeyCalavi $77 \mathrm{p}$.

FAO. (Food and Agriculture Organization), 1995. Le sorgho et les mils dans la nutrition humaine. FAO, Rome, Italie, $198 \mathrm{p}$.

Houssou, A.P., Dansou, V., et Mensah, G.A. 2014. Utilisation des variétés localement cultivées de riz pour la production duablo au Bénin. Fiche Technique $\mathrm{N}^{\circ} 2$. Dépôt légal $N^{\circ} 7652$ du 16/12/2014, $4^{\text {ème }}$ trimestre, Bibliothèque Nationale $(\mathrm{BN}) \mathrm{du}$ Bénin, $17 \mathrm{p}$.

Houssou, P., Dansou, V., Agro, A., Hounyèvou klotoé, A. et Akissoé, N. 2015. Mise au point et test d'un cuiseur à vapeur et d'un fermenteur pour la production du Ablo. Rapport d'activité projet 4/PPAAO/CNSMaïs. 21 p.

Leclerc, H., Buttiaux, R., Guillaume, J. et Wattre, P. 1977. Microbiologie appliquée. Doin Editeurs, Paris.

MAEP (Ministère de l'Agriculture, de l'Elevage et de la Pêche). 2013. Rapport général d'évaluation de la production vivrière en 2013. Cotonou, Bénin, 123 p.

Steinkraus, K.H. 1983. Handbook of indigenous fermented foods. Marcel Dekker Inc. My $688 \mathrm{P}$.

Tou, E.H. 2007. Caractérisation et amélioration du procédé traditionnel de préparation de la bouillie de mil fermenté, ben-saalga, utilisée comme aliment de complément au Burkina Faso. Thèse de doctorat, Sciences Biologiques Appliquées, Université de Ouagadougou, 200 p.

Wendorf, F., Close, A.E., Schild, R., Wasylikowa, K., Housley, R.A., Harlan, J.R. Krolok, H. 1992. Saharan exploitation of plants 8000 years BP. Nature, 359: 721-724.

\section{How to cite this article:}

Jultesse S.B. Banon, Innocent Yaou Bokossa, Célestin C.K. Tchekessi, Roseline Bleoussi, Pivot Sachi, Anayce Djogbe, Karl Assogba, Farid Bade, Edwige Dahouenon-Ahoussi, Azokpota Paulin and Guy Apollinaire Mensah. 2017. Production of Millet-Based (Pennisetum glaucum) Ablo and Sorghum-Based (Sorghum bicolor) Ablo Cultivated in the Republic of Benin. Int.J.Curr.Microbiol.App.Sci. 6(3): 276-282.

doi: https://doi.org/10.20546/ijcmas.2017.603.030 